\title{
P152: Reduction of the prevalence of cholera by observation of hand hygiene
}

\author{
T Koto ${ }^{*}$, AT Ahoyo, J Akpovij, M Mensah, Fanou, O Binazon \\ From 2nd International Conference on Prevention and Infection Control (ICPIC 2013) \\ Geneva, Switzerland. 25-28 June 2013
}

\section{Objectives}

Benin is endemic to epidemic area for diarrhea and cholrea in particular. The object is to present the result of the promotion campaign of sanitary measures which permit to reduce cholera spread in the studied area.

\section{Methods}

The study was focused on two areas affected by cholera in September 2012. The sensitization (close communication) during three months, by focus group in the families, interviews with people, direct observation of behavior of affected people was performed from September to December 2012. Inspections at place selling road food was added to the different actions.

\section{Results}

In an estimated population of 250000 the handwashing increased from $23 \%$ to $65 \%, 79 \%$ of 2183 contaminated wells and 189 tanks were systematically treated. Of 506 infected people, we have noticed 276 cured patients and 02 deaths. The remained were in observation at the end of the study.

\section{Conclusion}

Wells 'treatment coupled by handwashing with water and soap permitted to reduce the frequency of cholera in two sanitary areas. An intensive approach communication's work and health education is necessary to insert hands washing in our best practices.

\section{Disclosure of interest}

None declared.

Published: 20 June 2013

Health Ministry of Benin, Cotonou, Benin
doi:10.1186/2047-2994-2-S1-P152

Cite this article as: Koto et al:: P152: Reduction of the prevalence of cholera by observation of hand hygiene. Antimicrobial Resistance and Infection Control 2013 2(Suppl 1):P152.
Submit your next manuscript to BioMed Central and take full advantage of:

- Convenient online submission

- Thorough peer review

- No space constraints or color figure charges

- Immediate publication on acceptance

- Inclusion in PubMed, CAS, Scopus and Google Scholar

- Research which is freely available for redistribution

Submit your manuscript at www.biomedcentral.com/submit
() Biomed Central 